\title{
Impact of self-care modeling videos on people with spinal cord injury
}

\author{
Impacto dos vídeos simuladores de autocuidado na pessoa com lesão medular \\ Impacto de los vídeos simuladores de autocuidado en personas con lesión medular \\ Catarina Isabel Reis Silva Garcia e Teles de Araújo*
}

\begin{abstract}
Background: The amount of information provided by the new technologies has considerably changed how people search for information, leading to new triage needs.

Objectives: To produce evidence on how modeling videos can influence self-care and rehabilitation training of patients with spinal cord injury (SCI) in terms of motor skills and immediate knowledge.

Methodology: A quasi-experimental design was conducted to assess the impact of modeling videos on the motor skills and immediate knowledge acquisition.

Results: Motor skills have highly improved among the participants of the intervention group with the use of 3 videos. Moderate improvements were found with the use of 1 of the videos, whereas a slight improvement was found with the use of another video.

Immediate knowledge improvements were found for all of the techniques of the intervention group after comparison of both evaluation moments.

Conclusion: Videos have proved to have a positive impact on the intervention group both in terms of improved motor skills and immediate knowledge gains.
\end{abstract}

Keywords: instructional films and videos; rehabilitation; spinal cord injuries; self-care; motor skills

\section{Resumo}

Enquadramento: A amplificação da informação permitida pelas tecnologias atuais influencia a forma como as pessoas pesquisam a informação determinando novas necessidades de triagem.

Objetivos: Avaliar o impacto de um instrumento vídeo, em português, sobre técnicas de autocuidado e reabilitação motora em pessoas com lesão medular (LM) quanto a ganhos em habilidades motoras observáveis e ganhos em conhecimentos imediatos.

Metodologia: Realizou-se um estudo quasi-experimental de avaliação de impacto dos vídeos em ganhos de habilidades motoras e aquisição imediata de conhecimentos.

Resultados: Observou-se que o grupo de intervenção obteve ganhos de habilidades motoras muito significativos (pós-teste) em 3 dos vídeos estudados. Verificaram-se ganhos moderadamente significativos de desempenho com 1 dos vídeos e melhoria ligeira do desempenho com outro vídeo.

Encontrámos ganhos de conhecimentos imediatos em todas as técnicas do grupo de intervenção comparando os 2 momentos de avaliação.

Conclusão: A intervenção em estudo teve um impacto positivo no grupo de intervenção quer no aumento das habilidades de execução de técnicas quer no aumento dos conhecimentos imediatos sobre as mesmas.

Palavras-chave: filmes e vídeos educativos; reabilitação; traumatismos da medula espinal; autocuidado; destreza motora

\footnotetext{
* Ph.D., Specialist Nurse, Rehabilitation Medical Center of Alcoitão, 2649-506, Alcabideche, Portugal [garciacatarina@hotmail.com]. Address for correspondence: Rua Conde Barão - Alcoitão, 2649506, Alcabideche, Portugal.
}

\section{Resumen}

Marco contextual: El aumento de la información debido a las tecnologías actuales influye en la forma como las personas buscan información, lo que deriva en nuevas necesidades de clasificación. Objetivos: Evaluar el impacto de un vídeo en portugués sobre técnicas de autocuidado y rehabilitación motora en personas con lesión medular (LM) respecto a los beneficios en las destrezas motoras observables y en los conocimientos inmediatos.

Metodología: Se realizó un estudio casi experimental con el objetivo de evaluar el impacto de los vídeos en relación a los beneficios en las destrezas motoras y la adquisición inmediata de conocimientos.

Resultados: Se observó que el grupo de intervención obtuvo beneficios significativos en las destrezas motoras (después de la prueba) en 3 de los vídeos estudiados. Se constataron beneficios moderadamente significativos respecto al rendimiento con 1 de los vídeos y una ligera mejora del rendimiento con otro vídeo. Se encontraron beneficios respecto a los conocimientos inmediatos en todas las técnicas del grupo de intervención comparando los 2 momentos de evaluación.

Conclusión: La intervención en estudio tuvo un impacto positivo en el grupo de intervención tanto en el aumento de las destrezas de ejecución de técnicas como en el aumento de los conocimientos inmediatos sobre las mismas.

Palabras clave: películas y vídeos educativos; rehabilitación; traumatismos de la médula espinal; autocuidado; destreza motora

Received for publication: 26.10 .15

Accepted for publication: 19.02.16 


\section{Introduction}

In July 2012, a search using a well-known search engine (YouTube) and the keywords spinal cord injury returned 15,100 videos. At the moment (October 2015), more than 93,200 are registered. The number and diversity of videos on the Internet reflect the sharing of experiences, abilities, techniques or other information among people with spinal cord injury (SCI) as a way of helping their peers and their relatives/caregivers. The advent of digital platforms like YouTube or the virtual social networks like Facebook have irreversibly transformed the way people search and share health information for their benefit.

Health authorities are struggling to find compromise solutions between the inalienable duty of the Government as a provider of resources and health care services to the citizens and the duty of citizenship of protection and responsibility for the health of individuals, families and communities. The economic constraints in the care health services (Fedyshin, Burda, Epstein, \& Lawrence, 2005) and the large-scale familiarization of computerized media and broadband Internet in the community have promoted the development of innovative materials in health education by the professionals (Fedyshin et al., 2005; Kinnane, Stuart, Thompson, Evans, \& Schneider-Kolsky 2008). Although not intending to replace the professionals' guidance (Shah \& Velez, 2014), a video can include a considerable amount of information, leaving more time for health professionals to spend on treatment activities or direct care (Ruthman \& Ferrans, 2004).

This study aims to assess the impact of a video, in Portuguese, on self-care and motor rehabilitation techniques in people with spinal cord injury in terms of motor skills and immediate knowledge gains.

\section{Background}

In a study (Drainoni et al., 2004) involving 516 participants enrolled in a North-American database of people with SCI, 360 participants reported having Internet access. These participants also reported higher benefits and scored higher in the indicators of a health-related quality of life questionnaire. These authors concluded that people with SCI increasingly use the Internet for purposes of interpersonal communication, entertainment and leisure, information and shopping.

In modeling videos, the message receivers identify themselves with the social models in the video and perceive themselves as equally empowered people to perform their self-care activities or techniques (Armstrong, Idriss, \& Kin, 2011; Dyson, Beatty, \& Matthews, 2010; Shah \& Velez, 2014; Mahabee-Gittens, Vaughn, \& Gordon, 2010). Bandura's social learning theory and promotion of the self-efficacy belief support the use of videos in so far as they convey the observed experience of the performance of the others, their peers (Bandura, 1997).

The concept of rehabilitation encompasses multifaceted perspectives. The World Report on Disability cited by Groote, Bickenbach, \& Gutenbrunner (2011) argues that rehabilitation comprises appropriate measures to maintain maximum independence, full physical, mental, social and vocational ability, and full inclusion and participation in all aspects of life. In light of this commitment, this report urges the international community to organize and strengthen services and programs to address the needs for support products, assistive technologies and an inclusive attitudinal environment.

The development of certified modeling videos for this population should be a responsibility and a challenge for rehabilitation experts, with several thematic priorities. In addition to decreased body mobility and changes in muscle strength, the main consequences of SCI are altered respiratory function, ineffective cough, altered bladder function or neurogenic bladder, (requiring continuous or intermittent catheterization), altered bowel motility, with a tendency to constipation, pressure sores (implying the use of pressure relief equipment), heterotopic calcification leading to joint immobility, bone decalcification and osteoporosis with associated risk of bone fractures, high spasticity decreasing the quality of life for compromising mobility and self-care activities, and neurogenic pain (Heinemann, Steeves, Boninger, Groah, \& Sherwood, 2012; Hoeman, 1990; Henriques et al., 2007; Cardoso, Queirós, \& Margato, 2006). 


\section{Research questions}

What is the impact of modeling videos on self-care and rehabilitation techniques in the acquisition of motor skills by individuals with SCI?

What is the impact of modeling videos on self-care and rehabilitation techniques in the knowledge acquisition by individuals with SCI?

\section{Methodology}

A quasi-experimental study (pre-test/post-test) was conducted in an inpatient unit to assess the impact of the modeling videos on self-care and rehabilitation techniques in a population sample of individuals with spinal cord injury.

The video technology was the intervention used as health promotion instrument. To ensure that the study would be conducted in due time, we selected only some therapeutic activities of the rehabilitation program for people with SCI which were considered a priority by several authors (Hoeman, 1990; Henriques et al., 2007; Cardoso et al., 2006).

The modeling videos on the techniques under analysis (independent variables) selected to assess their impact on people with SCI were the incentive spirometer, push-up in a wheelchair, training curbs in wheelchair, transfer from wheelchair to car, and the standing-frame technique.

The participants were sequentially recruited (in a non-randomized way) in an inpatient unit of specialized motor rehabilitation in SCI. The participants were included in the study according to the following inclusion criteria: diagnosis of SCI with severely altered mobility and decreased muscle strength, involving several muscle groups below the level of SCI; ability to perform the techniques; Portuguese as mother language; aged between 18 and 70 years; hospitalization in a motor rehabilitation unit; and having already started the rehabilitation program for more than 15 days. The exclusion criteria were: illiteracy or cognitive impairment hindering communication and/or video watching; and, despite being diagnosed with SCI, not using a wheelchair when the study was conducted. The participants were referred to the main researcher by nurses specialized in rehabilitation of an inpatient unit (convenience sample).

The modeling videos on the techniques were displayed on a mobile device/tablet or DVD player/ laptop. In the intervention group, for each technique under analysis, eight people with SCI were selected in the inpatient unit (for more than 15 days). This technique would have to integrate the patient's rehabilitation plan. The same procedure was applied to the control group, thus avoiding biased results. The participants were filmed while performing the technique under analysis before $\left(\mathrm{T}_{1}\right)$ and $\operatorname{after}\left(\mathrm{T}_{2}\right)$ watching the modeling videos within a time interval of 3 days.

Following the same sampling criteria, the study with the participants of the control group was performed 6 months after the study with the intervention group to avoid sample contamination and, consequently, biased results. The control group was filmed again 3 days after the first shooting, without having access to the modeling videos.

Figure 1 exemplifies the type of study implemented.

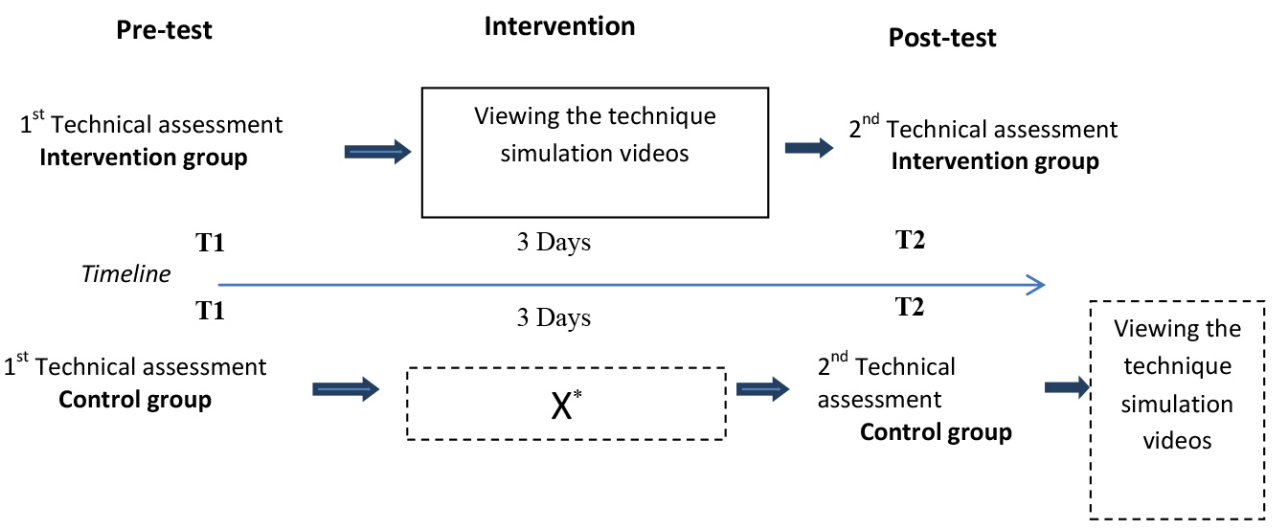

Figure 1. Quasi-experimental study with the intervention group and the control group.

$\mathrm{X}^{*}$ - no intervention between $\mathrm{T} 1$ and $\mathrm{T} 2$. 
The evaluation of the motor performance (dependent variable, in movie) at pre-test $\left(\mathrm{T}_{1}\right)$ and post-test $\left(\mathrm{T}_{2}\right)$ was carried out by five independent researchers. This procedure could minimize the potential error of having only one or two independent evaluations. A blind and independent evaluation allows for a more reliable/valid assessment to the extent that the independent raters were not aware of who had or had not received the intervention or if the video corresponded to the pre- or post-test phase of the study.

In each rehabilitation technique assessed, there are specific steps that should be followed to perform it as effectively and safely as possible. These steps were highlighted in the modeling videos. In each video, whenever the participant performed these steps (assessed using a check-list for each technique under analysis), a point was assigned for each step. No points were assigned if the participant missed a decisive step or action during the performance of the technique.

A total of 160 videos were produced, with non-structured data collection (five rehabilitation techniques for each of the eight participants from both groups: control and intervention in both moments - $\mathrm{T}_{1}$ and $\mathrm{T}_{2}$ ) for the evaluation of motor skills, the first dependent variable.

Knowledge assessment, which is the second dependent variable, was embodied in a semi-structured interview (four to five open-ended questions for each technique) to each participant during the footages $\left(\mathrm{T}_{1}\right.$ and $\left.\mathrm{T}_{2}\right)$. In the interview about each one of the techniques, it was possible to register what the participants perceived as being necessary to perform each technique, the safety steps that ensure its effectiveness, the resources needed, its advantages, and the recommended frequency of performance. This interview was part of a sociodemographic data collection: age, level of education, time since the diagnosis of the injury, number of admissions in rehabilitation units, Internet access and use by the interviewee or family caregivers/cohabiting people. The knowledge about each technique was assessed through a set of items encompassing the key aspects of each technique. The control group only had access to the educational videos after the videos were produced and the interviews were conducted.

In the statistical data analysis, we used parametric statistics after checking assumptions of normality and homogeneity.

The study was conducted after permission was requested to and granted by the Board of Directors of the Rehabilitation Center for conducting the interviews and applying the intervention to the intervention and control groups. In the SCI inpatient units, the participant selection was also subjected to approval by the Clinical Directors so as to ensure the participants' safety and comfort.

The informed consent delivered to the participants included information about the purpose of the study, who would have access to the videos, the lack of any exchanges of favors or monetary benefits between researcher and participant, the possibility of withdrawing at any time, the possibility of consulting research data at any moment of the process, and the obligation of keeping research data confidential. Upon the informed consent delivery, the participants were informed about the moments of the video recording of the techniques under analysis, the need for time availability and the resources required, and that, for the purpose of the study, both shootings were essential.

The pre-test questionnaires were performed in a private room without elements of distraction. The relatives or other patient could not be present and the room should remain silent (without visits, other patients, other professionals, no TVs/mobile phones or frequent hospital noises). After signing the informed consent for participation in the study, the participants started to complete the questionnaire in the presence of the researcher.

\section{Results}

Table 1 shows the results of the Student's $t$-test applied to analyze the mean scores assigned by the five independent raters to the motor performance of the participants in the intervention group (intervention group). 
Table 1

Assessment of the performance of the intervention group in five rebabilitation techniques

\begin{tabular}{|c|c|c|c|c|c|}
\hline Techniques under analysis & $\begin{array}{c}\text { Mean score of five } \\
\text { assessments }\end{array}$ & $\begin{array}{l}\text { Standard } \\
\text { deviation }\end{array}$ & $\begin{array}{c}\text { Mean difference } \\
\left(\mathrm{T}_{2}-\mathrm{T}_{1}\right)\end{array}$ & $\begin{array}{c}\text { Student's } \\
t \text {-test }\end{array}$ & $\begin{array}{l}\text { p-values } \\
\text { (2-tailed) }\end{array}$ \\
\hline Incentive spirometer - $\mathrm{T}_{1}$ & 3.06 & 1.56 & \multirow{2}{*}{-1.04} & \multirow{2}{*}{-3.623} & \multirow{2}{*}{$.001 * *$} \\
\hline Incentive spirometer - $\mathrm{T}_{2}$ & 4.10 & 1.04 & & & \\
\hline Push-up_T $T_{1}$ & 3.59 & 0.94 & \multirow{2}{*}{-0.26} & \multirow{2}{*}{-2.693} & \multirow{2}{*}{$.010 * *$} \\
\hline Push-up_T ${ }_{2}$ & 3.85 & 0.43 & & & \\
\hline Curbs_t $\mathrm{T}_{1}$ & 2.00 & 1.03 & \multirow{2}{*}{-1.82} & \multirow{2}{*}{-9.560} & \multirow{2}{*}{$.000 * * *$} \\
\hline Curbs_T & 3.82 & 0.82 & & & \\
\hline Car_t $\mathrm{T}_{1}$ & 3.03 & 0.74 & \multirow{2}{*}{-1.08} & \multirow{2}{*}{-9.097} & \multirow{2}{*}{$.000 * * *$} \\
\hline Car_t $\mathrm{T}_{2}$ & 4.10 & 0.598 & & & \\
\hline Standing-Frame $\mathrm{T}_{1}$ & 4.15 & 0.66 & \multirow{2}{*}{-0.18} & \multirow{2}{*}{-2.211} & \multirow{2}{*}{$.033^{* *}$} \\
\hline Standing-Frame $\mathrm{T}_{2}$ & 4.33 & 0.69 & & & \\
\hline
\end{tabular}

$* * p<.05 ; * * * p<.001$

The high statistical differences for the intervention group between pre-test and post-test are more evident in the following techniques: incentive spirometer $(p=.001)$, training curbs in wheelchair $(p=.000)$, and transfer from wheelchair to $\operatorname{car}(p=.000)$.

Given that the five independent raters performed a blind analysis of the videos, we sought to verify if the scores given to each participant were similar (interrater agreement). Thus, the agreement between the five independent raters was assessed using Kruskal-Wallis non-parametric test (Table 2).

Table 2

Interrater agreement between the independent raters according to technique and assessment moment

\begin{tabular}{lcc}
\hline Rehabilitation technique & Kruskal-Wallis Test & p-values \\
\hline Incentive spirometer $\mathrm{T}_{1}$ & 0.331 & .954 \\
Incentive spirometer $\mathrm{T}_{2}$ & 6.557 & .087 \\
Push-up T $_{1}$ & 0.688 & .876 \\
Push-up T & 0.094 & .993 \\
Training curbs in wheelchair $\mathrm{T}_{1}$ & 0.006 & 1.000 \\
Training curbs in wheelchair $\mathrm{T}_{2}$ & 0.045 & .998 \\
Transfer to car $\mathrm{T}_{1}$ & 0.046 & .997 \\
Transfer to car $\mathrm{T}_{2}$ & 0.018 & .999 \\
Standing frame $\mathrm{T}_{1}$ & 0.120 & .989 \\
Standing frame $\mathrm{T}_{2}$ & 0.221 & .974 \\
\hline
\end{tabular}

Table 3 shows the results of a statistical test (Wilcoxon Test) between the mean scores assigned by the five raters who watched the videos of the control group participants (in $\mathrm{T}_{1}$ and $\mathrm{T}_{2}$ ) through a blind evaluation.
The results of the Student's $t$-test pointed to differences without statistical significance in the control group (not submitted to the intervention).

Table 3

Assessment of the performance of motor skills in the five rehabilitation techniques (control group)

\begin{tabular}{|c|c|c|c|c|c|}
\hline Techniques under analysis & $\begin{array}{l}\text { Mean score between five } \\
\text { independent assessments }\end{array}$ & $\begin{array}{l}\text { Standard } \\
\text { deviation }\end{array}$ & Mean Ranks & Wilcoxon Test & p-values \\
\hline Spirometer_T1 & 4.533 & 0.776 & 9.06 & \multirow{2}{*}{-0.206} & \multirow{2}{*}{.837} \\
\hline Spirometer_T2 & 4.500 & 0.572 & 8.94 & & \\
\hline
\end{tabular}




\begin{tabular}{|c|c|c|c|c|c|c|}
\hline \multirow{2}{*}{ 2) } & Stand-Frame_T1 & 4.575 & 0.594 & 3.50 & \multirow{2}{*}{-1.663} & \multirow{2}{*}{.102} \\
\hline & Stand-Frame_T2 & 4.475 & 0.716 & 3.50 & & \\
\hline \multirow{2}{*}{ 3) } & Car_T1 & 3.378 & 0.758 & 5.63 & \multirow{2}{*}{0.000} & \multirow{2}{*}{1.000} \\
\hline & Car_T2 & 3.378 & 0.681 & 4.50 & & \\
\hline \multirow{2}{*}{ 4) } & Curbs_T1 & 3.250 & 1.316 & 12.00 & \multirow{2}{*}{-0.487} & \multirow{2}{*}{.626} \\
\hline & Curbs_T2 & 3.375 & 1.192 & 5.00 & & \\
\hline \multirow{2}{*}{ 5) } & Push-up_T1 & 3.872 & 0.339 & 0.00 & \multirow{2}{*}{-2.070} & \multirow{2}{*}{.038} \\
\hline & Push-up_T2 & 3.692 & 0.569 & 3.00 & & \\
\hline
\end{tabular}

In the control group, the interrater agreement between the five raters was very high. We only found a lack of agreement with statistical significance $(z=$ $2.07, p=.04$ ) in the push-up technique. However, this technique was less favorably assessed in the second moment of assessment $\left(\mathrm{T}_{2}\right)$, a fortuitous result, and therefore not significant for the study.
The knowledge gains on the techniques under analysis were assessed at the same time in both groups of participants (Table 4). Significant knowledge gains were found for all techniques in the intervention group $(p=.011)$.

In the control group, only two techniques showed significant gains: standing frame and transfer from wheelchair to car.

Table 4

Wilcoxon's Test on the mean scores of knowledge acquisition

\begin{tabular}{lccccc}
\hline Techniques under analysis & Group under study & Pre-test & Post-test & Wilcoxon & z-value \\
\hline \multirow{2}{*}{ Incentive spirometer } & G. Intervention & $1.63(2.07)$ & $9.50(0.93)$ & -2.536 & $.011^{* * *}$ \\
& G. Control & $2.63(2.33)$ & $2.63(2.33)$ & 0.000 & 1 \\
\hline \multirow{2}{*}{ Transfer to car } & G. Intervention & $2.38(1.41)$ & $5.88(0.36)$ & -2.539 & $.011^{* *}$ \\
& G. Control & $4.5(0.76)$ & $5.00(0.54)$ & -2.000 & .046 \\
\hline \multirow{2}{*}{ Standing frame } & G. Intervention & $5.62(1.30)$ & $9.88(0.36)$ & -2.536 & $.011^{* *}$ \\
& G. Control & $6.00(1.85)$ & $7.38(1.85)$ & -2.636 & $.008^{* *}$ \\
\hline \multirow{2}{*}{ Training curbs in wheelchair } & G. Intervention & $3.50(1.70)$ & $6.00(0.00)$ & -2.539 & $.011^{* *}$ \\
& G. Control & $5.13(1.46)$ & $5.13(1.46)$ & 0.000 & 1 \\
\hline \multirow{2}{*}{ Push-up } & G. Intervention & $2.00(1.07)$ & $4.88(0.36)$ & -2.555 & $.011^{* *}$ \\
& G. Control & $2.13(0.84)$ & $2.13(0.84)$ & 0.000 & 1 \\
\hline
\end{tabular}

- Mean; (SD) - standard deviation; ** $\mathrm{p}<.05$;

\section{Discussion}

The use of modeling videos on self-care and rehabilitation techniques improved the motor skills in the intervention group, which is consistent with previous studies (Shah \& Velez, 2014; Ruthman \& Ferrans, 2004; Zaffagnini, Russo, Muccioli, \& Marcacci, 2013; Cho \& Chambers, 2014; Armstrong et al., 2011; Dyson et al., 2010; Walker \& Podbilewicz-Schuller, 2005; Occa \& Sugs, 2015).

The participants' motor performance was assessed by five independent raters. In addition to the high interrater agreement with significance values very close to one ( $\mathrm{p} \approx 1$, Kruskal-Wallis Test) between raters, which demonstrates reliability, significant gains were found in the motor performance of the intervention group participants in the five techniques under analysis $(p=.001$ and $p=.000)$.

Significant knowledge gains were also found for all techniques in the intervention group $(p=.011)$, which is in line with other studies on the use of health promotion videos (Kinnane et al., 2008; Ruthman \& Ferrans, 2004; Cho \& Chambers 2014; Armstrong et al., 2011; Dyson et al., 2010). 
The moderate knowledge gains of the control group in these two techniques may be explained by the repetition of interview (Ribeiro, 2007).

Despite the positive results, the videos should not be used as a substitute for in-person learning, but as a complement, an element of discussion and interactive critical analysis whenever possible, as advocated by Gagliano (1988).

Despite the immediate results, it would be important to longitudinally assess the knowledge acquired by the users and number of times they watch these videos after their clinical discharge, for example 2 and 6 months after.

The use of video recording to assess the motor skills is a methodology that requires the implementation of complex strategies. In the rehabilitation inpatient unit, there are multiple concurrent activities for the participants and several technical resources/products are needed for the exercises to be performed. Gathering a significant sample of available participants with the necessary conditions for video recording is an intricate task.

With regard to the limitations of the study, it is important to consider the small sample size and the use of a non-randomized sample. However, given the ethical difficulties and constraints of experimental studies, adopted the methodology seemed to be useful for a first assessment of the effectiveness of the technique. Thus, further studies should be conducted with a more comprehensive population sample (multicenter studies) to proceed with the validation of the results found in this study.

\section{Conclusion}

Due to time constraints, the assessment of the impact of the modeling videos on rehabilitation and self-care techniques for individuals with SCI (main study) focused exclusively on five videos. In line with previous studies, we identified gains in terms of motor skills and knowledge on the self-care techniques under analysis among the participants in our study.

The control group obtained no statistically significant results in the assessment of motor skills, only moderate results in the push-up technique. However, a worst result was found in the second assessment moment. In the assessment of immediate knowledge gains about the self-care techniques under analysis, we also found significant gains in the intervention group ( $p=0.011)$ for all techniques.

This study has allowed for a better understanding of the suitability and impact of modeling videos on self-care techniques in SCI patients undergoing a motor rehabilitation process. The intervention was planned to meet a gap in the provision of teaching materials on motor rehabilitation. The assessment of its impact improves our understanding of learning/ teaching rehabilitation techniques as a process. We have identified some aspects that confirm the advantage of using modeling/instruction videos to obtain motor and knowledge gains. It has also increased our knowledge on the impact of the videos on users, which does not seem to be related to any of the independent variables under analysis (age, level of education, hospital length-of-stay, among others).

Future studies should analyze the use of modeling videos with other populations undergoing rehabilitation programs, such as amputees, stoma patients or post-surgical orthopedic rehabilitation patients. These longitudinal studies will allow studying in more depth the long-term impact of the videos on knowledge gains.

During the assessment of the modeling videos, some participants asked us to view the videos concerning their own performance of the techniques in order to improve their performance, as in the autoscopy technique used in pedagogical processes. Within the scope of the use of modeling videos on rehabilitation techniques, this information may be used in planning future interventions.

\section{References}

Armstrong, A. W., Idriss, N. Z., \& Kin, R. H. (2011). Effects of video-based, online education on behavioral and knowledge outcomes in sunscreen use: A randomized controlled trial. Patient Education \& Counselling, 83(2), 273-277. doi: 10.1016/j.pec.2010.04.033

Bandura, A. (1997). Self-efficacy and health behaviour. In A. Baum, S. Newman, J. Wienman, R. West \& C. McManus (Eds.). Cambridge handbook of psychology, health and medicine (2nd ed., pp. 191-193). Cambridge, United Kingdom: Cambridge University Press.

Cardoso, F. M., Queirós, P. J., \& Margato, C. A. (2006). Técnicas de reabilitação I ( $4^{\mathrm{a}}$ ed.). Coimbra, Portugal: Formasau.

Cho, N., \& Chambers, R. (2014). The potential of video in patient education post skin biopsies. University of Ottawa Journal of Medicine, 4(2), 32-35. doi: $\quad$ 10.18192/uojm.v4i2.1161 
Drainoni, M.-L., Houlihan, B., Williams S., Vedrani, M., Esch, D., Lee-Houd, E., \& Weiner, S. (2004). Patterns of internet use by persons with spinal cord injuries and relationship to health-related quality of life. Archives of Physical Medicine and Rebabilitation, 85(11), 1872-1879. doi: 10.1016/j. apmr.2004.07.350

Dyson, P. A., Beatty, S., \& Matthews, D. R. (2010). An assessment of lifestyle video education for people newly diagnosed with type 2 diabetes. Journal of Human Nutrition and Dietetics, 23(4), 353-359. doi: 10.1111/j.1365-277X.2010.01077.x

Fedyshin, M. K., Burda, M. L., Epstein, B. A., \& Lawrence, B. (2005). Collaborating to enhance patient education and recovery. Journal of the Medical Library Association, 93(4), 440-445. Retrieved from http://www.ncbi.nlm.nih.gov/pmc/ articles/PMC1250319/pdf/i0025-7338-093-04-0440.pdf

Gagliano, M. E. (1988). A literature review on the efficacy of video in patient education. Journal of Medical Education, 63(10), 785-792. doi: 10.1097/00001888-198810000-00006

Groote, M., Bickenbach, J., \& Gutenbrunner, C. (2011). The World Report on Disability: Implications, perspectives and opportunities for physical and rehabilitation medicine. Journal of Rehabilitation Medicine, 43(10), 869-875. doi: 10.2340/16501977-0872

Heinemann, A. W., Steeves, J. D., Boninger, M., Groah, S., \& Sherwood, A. M. (2012). State of the science in spinal cord injury rehabitlitation: Informing a new research agenda. Spinal Cord, 50(5), 390-397. doi: 10.1038/sc.2012.12

Henriques, F. M., Cruz, A. G., Afonso, J. A., Ferreira, M. B., Costa, M. C., \& Coimbra, M. M. (2007). Técnicas de Reabilitação II ( $2^{\text {a }}$ ed.). Coimbra, Portugal: Formasau.

Hoeman, S. P. (1990). Rehabilitation: Restorative care in the community ( $4^{\text {th }}$ ed.). St. Louis, MO: Mosby Company.

Kinnane, N., Stuart, E., Thompson, L., Evans, K., \& Schneider-Kolsky, M. (2008). Evaluation of the addition of video-based education for patients receiving standard pre-chemotherapy education. European Journal of Cancer Care, 17(4), 328339. doi: 10.1111/j.1365-2354.2007.00846.x

Mahabee-Gittens, E., Vaughn, L., \& Gordon, J. (2010). Youth and their parents' views on the acceptability and design of a video-based tobacco prevention intervention. Journal of Child \& Adolescent Substance Abuse, 19(5), 391-405. doi: 10.1080/1067828X.2010.515878

Occa, A., \& Sugs, S. (2016). Communicating breast cancer screening with young women: An experimental test of didactic and narrative messages using video and infographics. Journal of Health Communication: International Perspectives, 21(1), 1-11. doi: 10.1080/10810730.2015.1018611

Ribeiro, J. L. (2007). Metodologia de investigação em psicologia e saúde. Porto, Portugal: Legis Editora.

Ruthman, J. L., \& Ferrans, C. E. (2004). Efficacy of a video for teaching patients about prostate cancer screening and treatment. American Journal of Health Promotion, 18(4), 292-295. doi 10.4278/0890-1171-18.4.292

Shah, R., \& Velez, L. (2014). Effectiveness of software-based patient education on inhaler technique: A clinical study. European Respiratory Journal, 44(Suppl. 58). Retrieved from http:// use-inhalers.com/sites/default/files/publicationpdf/Clinical_ Study.pdf

Walker, M. S., \& Podbilewicz-Schuller, Y. (2005). Video preparation for breast cancer treatment planning: Results of a randomized clinical trial. Psycho-oncology, 14(5), 408-420. doi: 10.1002/pon.858

Zaffagnini, S., Russo, R. L., Muccioli, G. M., \& Marcacci, M. A. (2013). The VideoInsight ${ }^{\circledR}$ method: Improving rehabilitation following anterior cruciate ligament reconstruction: A preliminary study. Knee Surgery, Sports Traumatology, Arthroscopy, 21(4), 851-858. doi: 10.1007/ s00167-013-2392-4 